\title{
Ensuring Compliance with the Water Pollution Control Laws: Issues in Perspectives
}

\author{
Matome S. Rangata \\ Kola O. Odeku
}

Faculty of Management and Law, University of Limpopo, Turfloop, South Africa

\section{Doi:10.5901/mjss.2014.v5n23p2661}

\begin{abstract}
Virtually all the laws regulating water resources make it mandatory that water pollution laws must be strictly complied with and they also provide for adequate consequences for transgression of the laws. However, there are instances when these laws might be deliberately or inadvertently contravened. There are ample provisions in the laws to control and sanction the demeanor of the polluter and bring the polluter to account. This paper looks at the compliance mechanisms and the challenges thereof. It examines the court's activism in ensuring that perpetrators are made to comply and consequences that will follow for non-compliance.
\end{abstract}

Keywords: Regulations, Compliance, Contraventions, Polluters, Accountability, Justice

\section{Introduction}

The National Water Act 36 of 1998 (NWA or the Act) has transformed the regulatory regime governing water pollution control in South Africa by abolishing a private rights system of water allocation and replaced this system with a public rights system (Tewari, 2009). This allows water to be treated in an integrated fashion as "a resource common to all" wherever it occurs in the hydrologic cycle (Francis, 2005). For water to continue to be the most precious natural resource on planet earth, it has to be free of harmful substances and pollution (Allan, 2011). Therefore, the control of water pollution is considered significant worldwide including South Africa (Tebbutt, 1997). The prevention of pollution at source, the precautionary principle and compliance with water laws have become key elements of successful mechanisms for preventing, controlling and reducing water pollution at source (Helmer, et al. 1997).

The Act has also provided a mechanism for the state to give effect to certain constitutional obligations, such as the duty to provide equitable access to water, environmental protection and sustainable resource use, justifiable social and economic development, and effective recognition of the country's international obligations (Stein, 2004). It is through this mechanism that the Act compels compliance with the water pollution control laws. Pursuant to this, appropriate sanctions and consequences have been prescribed and will be imposed as penalties for contraventions. In terms of Section 152 of the NWA, the penalties may either be a fine or imprisonment for a period not exceeding five years, or both.

South African water pollution control laws are constantly being reformed to meet the challenges as they unfold (Saleth and Dinar, 1999). It is pertinent to point out that human activities are the major sources of water pollution ( Hutton and Symon, 1986) and as such, ample interventions have been made by the institutions responsible for ensuring clean and safe water for the well-being of all (Ukwandu, 2009). Human activities are hugely impacting on the water resources to the extent that it is causing unprecedented water scarcity (Postel, 2000). Explaining the impact of human activity on water scarcity Postel (2000) point out that "there are now numerous signs that human water use exceeds sustainable levels. Groundwater depletion, low or nonexistent river flows, and worsening pollution levels are among the more obvious indicators of water stress. In many areas, extracting more water for human uses jeopardizes the health of vital aquatic ecosystems. Satisfying the increased demands for food, water, and material goods of a growing global population while at the same time protecting the ecological services provided by natural water ecosystems requires new approaches to using and managing fresh water."

This problem needs to be nipped in the bud before it escalates to an uncontrollable disastrous situation hence, the need to strengthen compliance with water pollution control laws and measures. 


\section{Constructional Mandate to Protect Water Resource}

There is a strong linkage between the environment and water (Law et al. 2002). Water is part of environmental natural resources (Kahn, 2005). The environment and water need to be sustainably managed for present and future generation and the same argument apply to water (Loucks, 2000). Section 24 of the South Africa's Constitution Act 108 of 1996 affords every person the right to an environment which is not harmful to their well-being (Fuggle et al. 2009). The Constitution also placed a constitutional mandate on government to protect the environment through reasonable legislative and other measures that prevent pollution, ecological degradation, promote conservation and secure ecological sustainable development and the use of natural resources while promoting justifiable economic and social development (Van der Linden, 2010).

In order to give effect to the aforesaid constitutional mandate, South African environmental law has been subjected to an intense revision process since 1996 (Davis, 2006). The first law that was promulgated to give effect to this constitutional mandate was National Environmental Management Act. NEMA can be described as one of the most progressive developments in environmental norm setting which guides individuals, institutions and government in environmental decision making (Kotzé, 2007). Furthermore, it provides for a range of key elements such as environmental principles, co-operative governance, a duty of care, enforcement mechanisms and integrated environmental management (Kotzé, 2007-2008).

In an approach to strengthen this framework, various other specific environmental management acts have been promulgated which includes the promulgation of the National Environmental Management: Waste Act 59 of 2008 (Fuggle et al, 2009 ). In addition to specific environmental management legislation promulgated, South African Environmental law has seen numerous positive contributions through both the revision of, and amendments to laws regulating diverse thematic areas such as conservation, pollution, mining and water management (Fuggle et al, 2009).

Therefore, in South Africa, the state is under a duty to maintain clean and safe environment via environmental rights, entitlements and justice(Takacs, 2008). In the event of outbreak of any environmental problems and disasters, the state is obliged to devise, fund, implement, and supervise measures to provide relief to those in desperate need ( Van Wyk, 2007).

The Bill of Rights guarantees every South African the right of access to sufficient and clean/safe water by virtue of Section 27 (1) (b). In terms of section 27(2), the state is required to take reasonable legislative and other measures within its available resources to achieve the progressive realisation of this right. Section 24 directs the state to take reasonable legislative and other measures to prevent pollution, promote conservation and secure ecologically sustainable development and use of natural resource while promoting justifiable economic and social development. Water pollution control is also provided for in section 19 of the NMA. in the case of Harmony Gold Mining Company limited v Free State, Department of Water Affairs and Forestry 2005 JDR 0465 (SCA) the court interpreted this provision in line with the provision of section 24 which prescribed that reasonable measures must be taken to prevent pollution and this measure was extended to land owned by the polluters and the adjacent land.

The court also said that by contrast, "section 28(6) of NEMA was concerned with rehabilitation and remedial work; that is: where some damage had occurred and restoration needed to be effected. Such measures were necessary and not merely reasonable. On the other hand 'where reasonable measures were required and the person obliged to take them is thwarted by another landowner's refusal of access' the former would probably have done what can 'reasonably' be attempted. It was therefore not necessary for the legislature to say anything further about the purpose, scope and nature of 'reasonable measures."

The court observed that "there was nothing in the language of section 19 of the NWA to suggest that the 'reasonable measures' required were intended to be confined to the land of the person obliged to take such measures. The court held that the legislature intended by the term 'reasonable measures' to lay down 'a flexible test dependent on the circumstances of each case'. On the facts of the case, it was a reasonable anti-pollution measure to take steps, to prevent groundwater from the defunct mines reaching the active ones. This interpretation was in line with the constitutional section 24 and statutory anti-pollution objectives which, in terms of section 1(3) of the NWA, had to be preferred to an interpretation that did not give effect to such objectives. The requirement to undertake reasonable measures on the land of another would, furthermore, be for the account of the person undertaking the measures. In the case at hand, the mines were being asked to share the costs of the preventative measures. In the court's view, this kind of collaboration was not outside the scope of 'reasonable measures.' The appeal by Harmony was dismissed." 


\section{The Constitutional Duty to Respect by the State}

Section 7(2) of the constitution provides 'that the state must respect, protect, promote and fulfill the rights in the Bills of Rights. The duty to respect entails that, the state must take all steps, to provide and deliver adequate, safe and sufficient water to all citizens. Ample access to good water resource is therefore an obligation that must be fulfilled without any restriction or obstruction (Naude, 2002). The obligation of the duty to respect is well indicated in the High Court case which dealt with the disconnections of water services. In Manqele v Durban Transitional Metropolitan Council $2001 \mathrm{JOL}$ 8956;2002 6 SA 423 (D), the applicant an unemployed woman, who had occupied premises with seven children, sought a declaratory order that the discontinuation of water services to the premises was unlawful. The applicant argued that the by-laws in terms of which the water services were disconnected were against the Water Services Act. Because the applicant relied on her right to basic water supply as referred to in the Act and did not rely on the constitution, the Court agreed with the respondent's argument that as no regulations have been promulgated to give meaning to the right to basic water supply, the right that the applicant relied on had no content. As such, the court ruled in favour of the respondent.

The reasoning of the court supported measures to provide and the court said that where a person proves satisfactorily to the relevant water services provider that he or she is unable to pay for basic services, the service may not be discontinued. This decision is relevant to the issue of water pollution control because, if water is polluted, it will become scarce and diminish the constitutional mandate of access to fresh water (Glennon, 2004). In desperation for water, people might drink polluted water or opt for the use of unhygienic untreated river water (Borden, 2014). These acts negate ample access to water and they are flagrant impediments to right to access to clean and adequate water.

\section{Compliance with the Polluter Pays Principle}

According to Stein (2009), the aims of the NWA are to make efficient use of water easier and prevent unnecessary pollution. In particular, an owner, controller, occupier or user of land on which anything takes place that has caused or is likely to cause pollution of water resources must take all reasonable measures to stop such pollution or prevent it from happening as articulated in Section 19 of the Act. Therefore, this section places a positive duty on a person to avoid polluting water resources. It also gives the state the power to enforce this duty of care by issuing remediation directives to the persons where pollution has taken place.

With regard to the remediation directives, the court approved of what the Minister of Water Affairs did in the case of Harmony Gold Mining Company limited v Free State, Department of Water Affairs and Forestry2005 JDR 0465 (SCA) by issuing a directive under the National Water Act's anti-pollution section requiring the erring company to take responsibility by abating pollution from their mines. The court gave tacit approval to the anti-pollution measures which was wide enough to require Harmony to take such measures not only in its own mine, but also, on the facts of the case, in the mines of the other companies.

\section{Ample and Unrestricted Access to Information}

In terms of section 32 of the constitution, citizens are guaranteed access to information and as such, any information that is given regarding the use of water resources will be in line with the constitution therefore valid ( Klaaren, 2005). Similarly, the right to information is also well enshrined in the Act. This enables adequate information on what the laws state and the compliance mechanisms, the laws regulating water and usage, water pollution control, monitoring, recording, assessing and disseminating of information on water resources. These are all critical to the achievement of the objectives of the Act. Section 142 of the Act requires that any information contained in any public and private institutions must be made available to the public by the minister. Water management institutions, which include catchment management agencies and water user associations, are also obliged to make information at their disposal available to the public. This includes information pertaining to flood warning; drought; any risk imposed by the quality of water to life, health, or property; as well as any other matter that may be necessary to achieve the objectives of the NWA by virtue of section 145.

The constitutional right concerning access to information is also relevant with respect to water pollution control. Section 32 of the constitution provides that "everyone has the right of access to-any information held by the state; and any information that is held by another person and that is required for the exercise or protection of any rights. National legislation must be enacted to give effect to this right, and may provide for reasonable measures to alleviate the administrative and financial burden on the state." 
South Africa is currently experiencing unprecedented water scarcity (Bakker, 2003). Pollution is exacerbating the problem. Ample information on water pollution control is imperative (Mathipa and Roux, 2009). Polluters also need to be informed of the relevant information regarding sanctions for water pollution. All actions including legal and remedial should be employed to tackle water pollution (Kraemer and Choudhury, 2001).

\section{Ensuring Compliance with Common Law Duty of Care}

Although provisions controlling water pollution appear in statutory law, some can be found in the context of common law, particularly nuisance and neighbor law (Allan, 2003). Therefore, the courts have been consistent in applying common law duty of care where it is necessary, and have been compelling compliance. The court articulated the significance of the common law duty in the case of Rainbow Chicken Farm (Pty) Ltd v Mediterranean Woollen Mills (Pty) Ltd 19631 SA 201, and held that "the producer of the effluent, quite apart from the statutory duties imposed upon him by section. 21 (1) and (2) (of the Water Act 1956), owes a common law duty of care towards others." The court indicated that "where the producer of effluent discharges it from his factory into a public stream and pollutes it, both in the sense that it does not conform to the standards laid down in terms of the statute and that it amounts to pollution at common law, an injured third party may elect whether to proceed against the producer for breach of the statutory duties or under the common law." The significant of this case is that it creates a duty of care for the producer of the effluent to prevent it from causing harm to others. This is crucial as everybody is expected to control his or her behavior and refrain from harming others.

The court also provides ample and satisfactory interpretation of the law of delict and the intention of the legislature to impose an obligation to prevent escape of noxious and harmful substances and detailed appropriate compensation as damages to the aggrieved person. This position was explicitly explained in the case of Lascon Properties (Pty) Ltd v Wadeville Investment Co (Pty) and Another 19974 SA 578, where the escape of water containing injurious matter from the mine was in issue. The mines and works regulations prohibited the escape of such water without having been rendered innocuous. The purpose of the regulation was to benefit the owner of land which might be polluted as a result of the actions of a mining company. The court held that the legislature would not have imposed an obligation to prevent the escape of noxious water without intending persons harmed thereby to be entitled to be compensated by the person permitting the water to escape. The legislature intended to provide a civil remedy for damage caused by a breach of the regulation extending beyond a mere interdict. The law of delict may be used to recover damages caused as a result of polluted water from mining activities (Halter and, Thomas, 1982).

\section{Application of Strict Liability Principle}

In South Africa, duty of care was incorporated as part of section 28 of the Act while in chapter 5 of the Act, strict liability on mitigating the causality problem is enshrined and stipulates that persons responsible for causing pollution should take reasonable measures to remedy such pollution. The concept of strict liability simply means that a person who commits pollution should remedy such pollution (O'Keefe, 1989). The United Kingdom decision in the case of Cambridge Water Co v Eastern Counties Leather plc Court of Appeal (Sir Stephen Brown, president, Lord Justice Mann and Lord Justice Nolan), 19 November 1992, affirmed this principle and the court held that "the plaintiff was entitled to an injunction to restrain the defendant from using his well so as to pollute the water in the plaintiffs well and also to damages for the injury which he had suffered by such pollution. It was further stated that, it was immaterial that both the plaintiff and defendant were not adjacent landowners, because the same aquifer was beneath the surface of each ownership, and that Tomlinson had caused the contamination by deliberately putting filth and waste into a well on his land, while the defendant's perchloroethane had been spilt completely by accident."

The above case is a clear indication that United Kingdom takes water pollution as a serious offence to the extent that the polluters are held strictly liable for their actions (Mylrea, 1998). If the principle of strict liability is properly implemented in South Africa as did in the UK, this will help strengthen water pollution control and the perpetrators will be made to account by insisting that they should do the right thing. The point that the court intended to prove was that one is liable for water pollution even though that particular person was not directly affected by such water pollution.

\section{Sanctions for Non-Compliance with Water Pollution Control Laws}

The NWA creates an offence for unlawfully and negligently committing any act or omission which pollutes or is likely to pollute a water resource (Algotsson et al. 2009). It is an offence to unlawfully and intentionally or negligently commit any act or omission which detrimentally affects or is likely to affect a water resource (Grobler, 2012). Any person who fails to 
comply with a directive issued under the prevention and remedying effects of pollution or control of emergency incidents commits an offence.

Any person who contravenes any of these provisions is guilty of an offence and liable, on the first conviction, to a fine or imprisonment for a period not exceeding five years, or to both- Section 152. In the case of a second or subsequent conviction, the offender is liable to either a fine or imprisonment for a period not exceeding ten years or to both. The fine is not determined with regard to this offence. However, it can be ascertained by the application or use of Adjustment of Fines Act 101 of 1991 it stipulates that: "if any law provides that any person on conviction of an offence may be sentenced to pay a fine the maximum of which is not specified or, in the alternative, to undergo a prescribed maximum period of imprisonment, and there is no indication to the contrary, the maximum fine which may be imposed shall be an amount which in relation to the said imprisonment is in the same ratio between the amount of the fine which the Minister of Justice may from time to time determine in terms of section 92 (1) (b) of the Magistrates' Court Act Act 32 of 1944, and the period of imprisonment as determined in section 92 (1) (a) of the said Act, where the court is not a court of a regional division."

The NWA provides for a fine or five years imprisonment, or both, for the first offender and a fine or ten years imprisonment for a subsequent conviction. The maximum appropriate fine is R 100000 for the first offender or R 200000 fine for a second or subsequent conviction. The Adjustment of Fines Act applies both to instances where a maximum fine is not provided for, and in those cases where there is a prescribed fine, which suggests that it can be used to update inadequate provision for fine in legislation (O'Hear, 2004.). There is a low rate of successful criminal prosecutions for environmental offences in South Africa. This is because environmental officers choose to initiate proceedings only if they have enough evidence to secure a conviction (Akech and Mwebaza, 2010). They however unintelligently prosecute environmental crimes as observed in the case of Kebble v Minister of Water Affairs [2007]SCA 111 (RSA) thus "an order that a person is in contempt of Court, which carries with it criminal sanctions, should be made only where the order allegedly flouted is clear and capable of enforcement. The Court further reasoned that the order made by the High Court that SGM comply with the directives of the Department was unclear because the directives themselves were unintelligible in several respects and to some extent also incapable of implementation. There was not, in the circumstances, any wilful failure to comply with the order. The court could not hold the Directors of SGM to be in contempt of court but it held that they had a duty of care to ensure that the underground water is treated and that pollution of underground water is controlled."

\section{Conclusion}

It is a common saying that water is life. Everyone acknowledges water as the most precious natural resource because of its unending usefulness for both living and non-living things on earth. It is therefore not surprising that our Constitution entrenches the right of access to water to all. The need to preserve water is a responsibility that affects all spheres of governments even though, government spheres are distinctive, interdependent and interrelated. Collaboration among government institutions would definitely strengthening and ensure compliance with water pollution control laws.

It is evidentially clear that the Courts had played and should continue to play important roles in ensuring that proper interpretation of water pollution control laws and measures are handed down in order to enforce compliance.

\section{References}

Akech M, Mwebaza R 2010. Enforcement of Environmental Crime Laws: A framework training manual for law enforcement agencies.From http://dspace.africaportal.org/jspui/handle/123456789/31081. (Retrieved 12 June, 2014).

Algotsson E, Murombo T, Davis M, Poole M 2009. Water Supply and Sanitation in South Africa: Environmental Rights and Municipal Accountability. From http://cer.org.za/wp-content/uploads/2011/11//hr-dbsa_water_report.pdf. (Retrieved 12 July, 2014).

Allan A 2003. Comparison between the Water Law Reforms in South Africa and Scotland: Can a Generic National Water Law Model Be Developed from These Examples. Natural Resources Journal, 43: 419:428.

Allan T 2011. Virtual water: tackling the threat to our planet's most precious resource. I.B Tauris \& Co Ltd, New York, USA.

Bakker K 2003. Archipelagos and networks: urbanization and water privatization in the South., The Geographical Journal. 169(4): 328341.

Borden S 2014. Thirsty City: Politics, Greed, and the Making of Atlanta's Water Crisis. State University of New York Press, Albany, New York, USA.

Davis DM 2006. Adjudicating the socio-economic rights in the South African Constitution: Towards' deference lite'? South African journal on human rights, 22(2): 301-327.

Francis R 2005. Water Justice in South Africa: Natural Resources Policy at the Intersection of Human Rights, Economics, and Political 
Power. Georgetown International Environmental Law Review, 18:149

Fuggle RF, Rabie MA, Strydom HA, King ND 2009. Environmental Management in South Africa. Juta \& Co, Cape Town, South Africa.

Fuggle RF, Rabie MA, Strydom HA, King ND 2009. Environmental Management in South Africa. Juta Law \& Co Ltd, Cape Town, South Africa.

Glennon R 2004. Water Scarcity, Marketing, and Privatization. Texas Law Review, 83:1873-1882.

Grobler R 2012. Regulating the environmental impacts of factory farming in South Africa: legal perspectives. From http://dspace.nwu.ac.za/handle/10394/9053. (Retrieved 6 July, 2014).

Halter F, Thomas J T. 1982. Recovery of Damages by States for Fish and Wildlife Losses Caused by Pollution. Ecology Law Quarterly, 10:5-12.

Helmer R, Hespanhol I, Supply W 1997. Water pollution control: a guide to the use of water quality management principles.From http://www.who.int/water_sanitation_health/resourcesquality/watpolcontrol.pdf. (Retrieved 1 May, 2014).

Hutton M, Symon C 1986. The quantities of cadmium, lead, mercury and arsenic entering the U.K. environment from human activities. Science of The Total Environment, 57(1):129-150.

Kahn JR 2005. the economic approach to environmental and natural resources. http://www.sidalc.net/cgiin/wxis.exe/?isisscript=inia.xis \&method=post\&formato=2\&cantidad=1\&expresion=mfn=032809. (Retrieved 2 January, 2014).

Klaaren J 2005. A second look at the South African Human Rights Commission, access to information, and the promotion of socioeconomic rights. Human Rights Quarterly, 27(2): 539-561.

Kotzé LJ 2007. Critical Survey of Domestic Constitutional Provisions relating to Environmental Protection in South Africa. Tilburg Law Review, 14:298-3007.

Kotzé LJ 2007. The Judiciary, the Environmental Right and the Quest for Sustainability in South Africa: A Critical Reflection. Review of European Community \& International Environmental Law, 16(3):298-311.

Kraemer RA, Choudhury K 2001. Protecting water resources: Pollution prevention. From http://storage.globalcitizen.net/data/topic /knowledge/uploads/20130207134951731526_pollution.pdf. (Retrieved 1February, 2014).

Law B.E, Falge, E, Gu L, Baldocchi DD, Bakwin P, Berbigie P, Davis K, Dolman AJ, Falk M, Fuentes JD, Goldstein A, Granier A, Grelle A, Hollinger D, Janssens IA, Jarvis P, Jensen NO, Katul G, Mahli Y, Matteucci G, Meyers T, Monson R, Munger W, Oechel W, Olson R, Pilegaard K, Paw KT, Thorgeirsson H, Valentini R, Verma S, Vesala T, Wilson K, Wofsy S 2002. Environmental controls over carbon dioxide and water vapor exchange of terrestrial vegetation. Agricultural and Forest Meteorology. 113(1-4): 97-120.

Loucks DP 2000. Sustainable Water Resources Management. Water International. 25(1): 3-10.

Mathipa KS, Le Roux CS 2009. Determining water management training needs through stakeholder consultation: building users' capacity to manage their water demand. From http://www.scielo.org.za/scielo.php?pid=S18169502009000300003 \&script=sci_arttext\&tlng=en. (Retrieved 11 August, 2014).

Morne Van der Linden, Compendium of South African Environmental legislation-2 ${ }^{\text {nd }}$ edition published in 2010.

Mylrea K 1998. Recent UK legal developments relating to pollution of water resources. Geological Society, London, 12(8): 15-21.

Naudé B 2002. Crimes against the environment. Acta Criminologica, 15(3): 21-38.

O'Hear MM 2004. Sentencing the green-collar offender: Punishment, culpability, and environmental crime. Journal of Criminal Law and Criminology, 95(1): 133-276.

O'Keefe, Constance 1989. Transboundary Pollution and the Strict Liability Issue: The Work of the International Law Commission on the Topic of International Liability for Injuries Consequences Arising out of Acts Not Prohibited by International Law. Denver Journal InternationalLaw\&Policy,18:145-156.

Postel SL 2000. Entering an era of water scarcity: the challenges ahead. From http://www.esajournals.org/doi/abs/10.1890/1051. (Retrieved 24 April, 2014).

Saleth RM, Dinar A 1999. Water challenge and institutional response: A cross-country perspective From http://dlc.dlib.indiana.edu/dlc /handle/10535/8466. (Retrieved 2 January, 2014).

Stein R 2004. Water Law in a Democratic South Africa: A County Case Study Examining the Introduction of a Public Rights System. Texas Law review, 83: 2167-2176.

Stein R, Levetan S, Christie L, Frittelli C, Sonnenbergs EN 2009. South Africa, Evnrionment. From www.practical law.com/8-422-442. (Retrieved 17 April, 2014).

Takacs D 2008. Public Trust Doctrine, Environmental Human Rights, and the Future of Private Property. New York Environmental Law Journal, 16:711-719.

Tebbutt THY 1997. Principles of water quality control. Butterworth-Heinemann, Massachusetts, USA.

Tewari dd 2009. A detailed analysis of evolution of water rights in South Africa: An account of three and a half centuries from 1652 AD to present. Water SA (Online)35(5): 693-710.

Ukwandu DC 2009. Water use and sustainable development in South Africa. From http://uir.unisa.ac.za/handle/10500/3482. (Retrieved 29 March, 2014).

Van Wyk J 2007. The complexities of providing emergency housing assistance in South Africa. From http://reference.sabinet.co.za Isa_epublication_article/ju_tsar_2007_n1_a3. (Retrieved 26 April, 2014). 